\title{
Research Article \\ Weathering Influence on Properties of Siltstones from Istria, Croatia
}

\author{
Martina Vivoda Prodan and Željko Arbanas \\ University of Rijeka, Faculty of Civil Engineering, Radmile Matejčić 3, 51000 Rijeka, Croatia \\ Correspondence should be addressed to Željko Arbanas; zeljko.arbanas@gradri.uniri.hr
}

Received 31 March 2016; Revised 3 June 2016; Accepted 7 June 2016

Academic Editor: Jianxi Zhu

Copyright ( 2016 M. Vivoda Prodan and Ž. Arbanas. This is an open access article distributed under the Creative Commons Attribution License, which permits unrestricted use, distribution, and reproduction in any medium, provided the original work is properly cited.

\begin{abstract}
Slaking and weathering of weak rocks result in slope instability. Siltstones from flysch rock masses are highly susceptible to weathering, which causes rapid changes in the geotechnical properties and durability. This study investigated siltstone samples of different weathering grades from flysch rock masses from the Istria Peninsula, Croatia, and determined the effects of weathering on their engineering properties. Laboratory testing of siltstone samples of different weathering grades was conducted to determine the specific gravity, grain size distribution, Atterberg limits, and uniaxial compressive strength. The standardized slake durability index is not sufficient to classify the durability of weak rock masses such as siltstones. Therefore, the durability of siltstone samples of different weathering grades was quantified from the fragment size distribution after each of five slaking cycles. The tested samples were classified based on the disintegration ratio, and the modified disintegration ratio was used to determine potential longterm degradation of the tested samples. The results indicated that weathering has a significant influence on the plasticity, uniaxial compressive strength, and durability characteristics and thus affects the landslides and erosion processes in siltstones in the flysch zone of the Istria Peninsula.
\end{abstract}

\section{Introduction}

The study area of this investigation is the Pazin Paleogene flysch basin, which is located in the northeastern part of the Istrian Peninsula, Croatia. Numerous landslides and erosion processes occur on the slopes in this area and are most often related to the weathering of flysch rock masses. Weathering is the process of the alteration and breakdown of rock and soil materials at or near the Earth's surface by chemical, physical, and biological processes that generally operate together $[1,2]$. Weathering causes mineralogical and lithological changes in rocks and consequently changes in their engineering properties. Many researchers have investigated weathering processes in sedimentary rocks. Chandler [3] and Reißmüller [4] investigated the effect of weathering on the shear strength of marls based on direct shear tests. The effects of chemical weathering of sedimentary rocks were described by Chigira and Oyama [5]. Bhattarai et al. [6] investigated the influence of weathering on the properties of mudstone. Durability is defined as the rock's ability to resist degradation during its working life [7]. It is considered to be dependent on several parameters, such as permeability, porosity, adsorption, mineralogy, microscopic texture, microfabrics, and the presence of microfractures [8-13]. This makes characterizing the slaking behavior in rocks using a single parameter extremely complex [14]. The slake durability test, which was proposed by Franklin and Chandra [9], is the most widely used test for evaluating the relationship between slaking and the durability of rocks. This test is recommended by both the International Society for Rock Mechanics [15] and the American Society for Testing and Materials [16]. However, the use of the denominated slake durability index in the second cycle $\left(\mathrm{I}_{d 2}\right)$ to quantify a rock's susceptibility to slaking is not satisfactory for characterizing weak rocks $[8,11,12,17]$. Because the observed weathering of rocks during testing is much greater than what is predicted by the slake durability test, new classifications of weak rocks have been proposed by several authors. Erguler and Shakoor [12] proposed a durability classification for clay-bearing rocks based on the disintegration ratio. This method quantifies 
the fragment size distribution of the slaked material by calculating the disintegration ratio for five slaking cycles. A new weathering characterization based on a newly proposed potential degradation index was introduced by Cano and Tomás [18]. This method analyzes changes in the fragment size distribution curves that are obtained from the material that is retained in the testing drum after each slake cycle. Behavior that is observed in the laboratory was compared to the behavior that is observed in the field under natural climatic conditions, investigated by Cano and Tomás [13].

The main aim of this paper is to describe changes in the durability and geotechnical characteristics of siltstones from flysch rock masses in the Istria Peninsula, Croatia, due to weathering processes. The field properties of siltstones of different weathering grades were determined visually, while Schmidt hammer rebound tests were performed to determine the uniaxial strength in the field. Physical and mechanical tests were performed to determine the specific gravity, grain size distribution, Atterberg limits, and point load strength of siltstone samples of different weathering grades. Five cycles of the slake durability test were performed, and the changes in the fragment size distribution curves that were obtained from the material that was retained in the testing drum after each cycle were analyzed. Based on the results of these analyses, the influence of weathering on the geotechnical properties and durability of siltstones of different weathering grades from flysch rock masses was identified and discussed.

\section{Geological and Morphological Characteristics of the Study Area}

The Istrian Peninsula is located in the northwestern part of the Adriatic Sea and is composed of Paleogene flysch, Cretaceous and Jurassic limestone, and alluvial deposits (Figure 1; [19]). It can be divided into three major regions: (i) Red Istria-Jurassic, Cretaceous, and Eocene plains (southern and western part of the Istria Peninsula); the term originates from the thick Quaternary deposits of so-called "terra rossa," which overlie the Mesozoic and Tertiary carbonate bedrock; (ii) White Istria-the Cretaceous Eocene carbonate platform and clastic zone (mainly the Ćićarija and Učka massifs), which have a characteristically imbricated structure; the term originates from the white color of the weathered Cretaceous and Eocene limestone; (iii) Gray Istria-the Eocene flysch basin (northeastern part of the Istria Peninsula). The term originates from the gray color of the marls, which are interbedded with sandstones and together form the flysch rock mass complex.

The study area includes the Gray Istria area, which is composed of a flysch rock mass that is a sequence of alternating clastic sedimentary rocks of deep marine facies that were deposited during an early stage of orogenesis [20]. The kinematics of the structural elements on the margin between the overthrust carbonate unit, Cićarija Mountain, and the Paleogene flysch basin are based on the relationship between the relatively rigid (limestone carbonate rocks) and relatively ductile (flysch rock mass complex) units during simultaneous deformation. The effects of the deformation are most distinctive at the contact (overthrust zone) between the limestone and the flysch rock mass complex. The deformation caused the relatively rigid limestone rock blocks to be pushed into the more ductile flysch [21].

In the study area, the flysch rock mass is characterized by lithological heterogeneity because of common vertical and lateral changes in the lithological sequences, which include marls, siltstones, and fine-grained sandstones as well as distinctive calcarenite layers (Figure 2). The flysch rock mass is characterized by high erodibility and low durability of its incompetent members, and it is almost completely covered by weathered surficial material and rock fall talus that are susceptible to sliding [22] except in isolated areas, where the erosion is better expressed [21]. Many small-scale landslides in flysch slopes, primarily rotational and translational slides, tend to occur along slip surfaces that are located at the contact between the surficial deposits and the flysch bedrock, within the colluvial surficial deposits (Figure 3(a)) [23], within the flysch rock mass (Figure 3(b)) [24], or as debris flows (Figure 3(c)) [21]. Intense erosion processes are also observed in the flysch deposits in the study area (Figure 3(d)) $[25,26]$. These geomorphological processes occur due to the significant influence of weathering in the flysch deposits and especially in the siltstone component, which has low durability and high susceptibility to weathering. Weathering decreases the residual shear strength of the siltstones, which results in landslide processes in the flysch deposits.

\section{Characterization of the Effects of Weathering on the Flysch Rock Mass}

Weathering causes changes in the mineralogical composition of a rock that affect its color, texture, composition, firmness, and form. In general, weathering includes two dominant types of processes: physical and chemical weathering processes [7]. Chemical weathering due to chemical reactions leads to the decomposition of the constituent minerals to stable or metastable secondary mineral products [27]. Physical weathering causes disaggregation and strength degradation of rocks. Drying-wetting cycles are likely the primary cause of the degradation of flysch rock masses [28]. A flysch rock mass can have diverse physical and mechanical properties depending on its lithological composition and state of weathering. Weathering processes are particularly expressed in incompetent members, such as claystones, shales, and siltstones. In contrast, sandstones, limestone, and breccioconglomerates are competent members and are considerably more resistant to the influences of exogenetic forces [29]. This study focuses on siltstones, which are the component of the flysch complex that is most susceptible to weathering. Therefore, the mechanical behavior of siltstones has the greatest influence on the behavior of the overall flysch rock mass complex. Figure 4 shows the high degradation of a flysch rock mass due to weathering in flysch pillars that were exposed to atmospheric conditions for seven years. These processes gradually transformed the fresh rock mass to residual soils and caused changes in its mineralogical composition and reductions in its mechanical properties. 


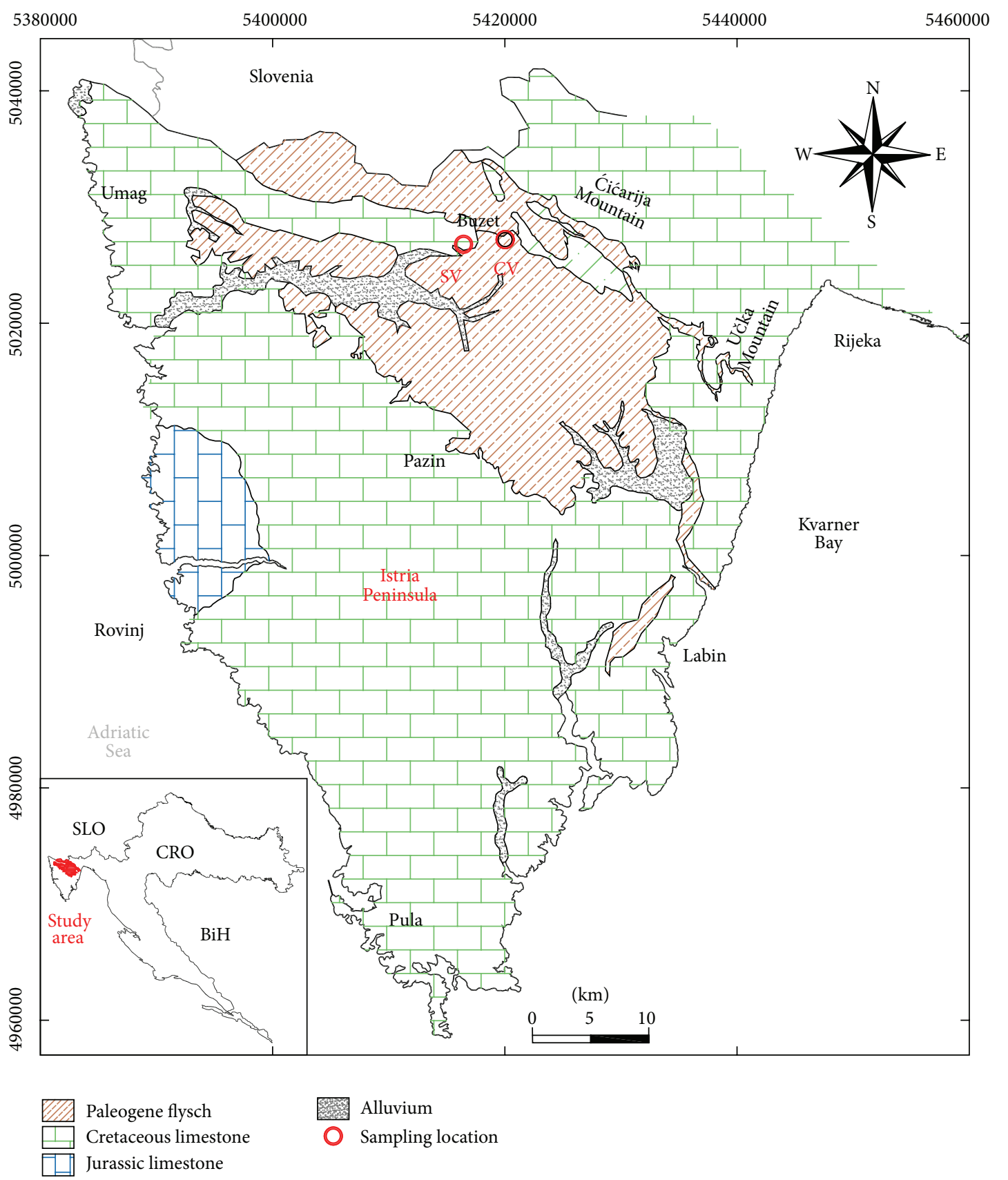

FIGURE 1: Geological map of the Istria Peninsula (based on [19]). CV = Cunj Village, SV = Sovinjak Village.

In this study, six standard grades of weathered siltstone [15] were investigated in a flysch weathering profile (Figure 5(a)). The weathering profile was defined using the following categories: fresh (FR), slightly weathered (SW), moderately weathered (MW), highly weathered (HW), and completely weathered (CW) rock masses and residual soil (RS). The evaluation of the weathering profile in the study area was based on a qualitative description of the colors and discoloration, discontinuities states, the existence or absence of the original rock texture, and the uniaxial compressive strength of the intact rock based on the Schmidt hammer rebound value. Progressive and gradual weakening and decomposition take place from the ground surface downward to fresh rock, and thus the weathering of the flysch rock material decreases from RS to CW, HW, MW, SW, and FR. Vivoda Prodan et al. [30] performed X-ray diffraction mineralogical analyses of siltstone samples of four different weathering grades, including I (FR), III (MW), V (CW), and VI (RS), that were taken from a flysch outcrop near Cunj Village on the Istria Peninsula. The siltstone samples of the different weathering grades consist of small amounts of quartz and calcite, negligible amounts of plagioclase, and large amounts of clay minerals. Based on dissolution (calcite and chlorite) and a comparison with standard diffractograms, 


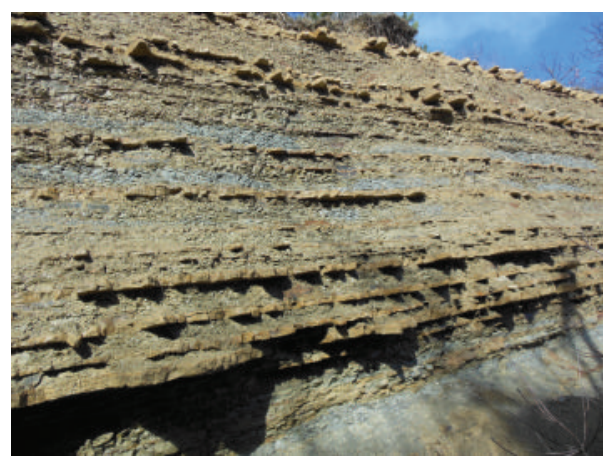

FIGURE 2: Vertically alternating sandstones and siltstones in the flysch rock mass at the lateral scarp of the Brus Landslide in the Istria Peninsula.

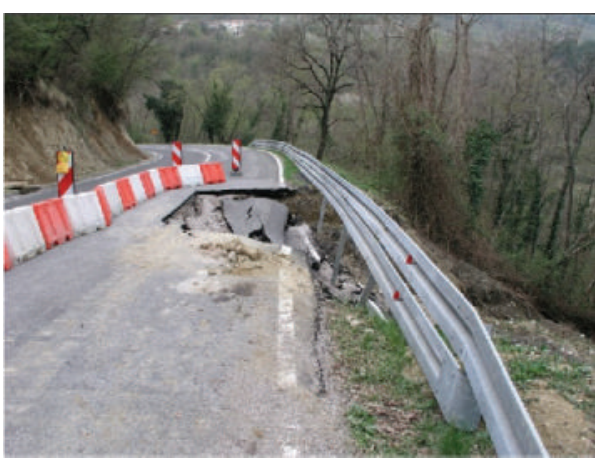

(a)

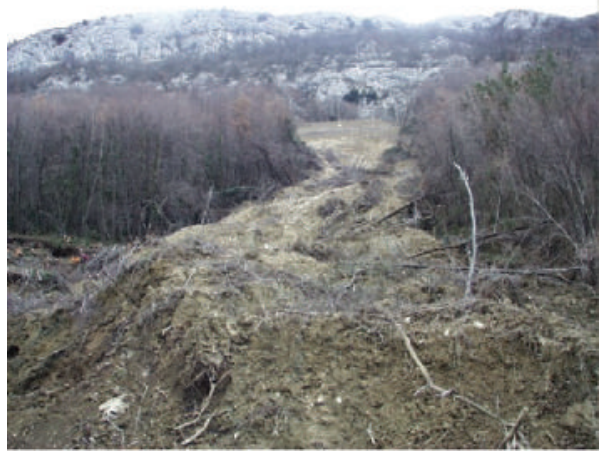

(c)

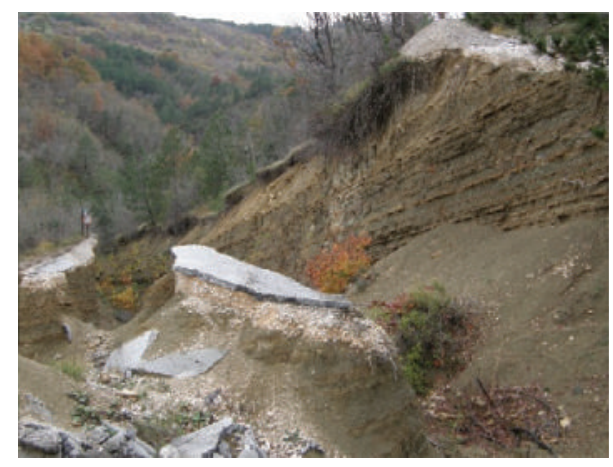

(b)

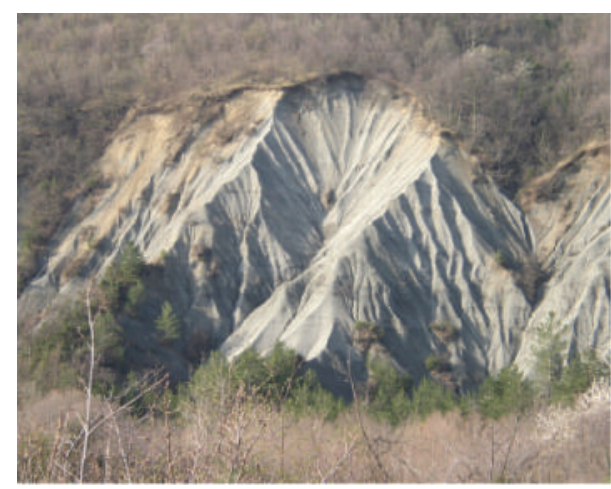

(d)

FIGURE 3: Geomorphological processes at the study area: (a) the rotational Marinci Landslide, (b) the translational Brus Landslide, (c) a debris flow at Krbavčići, and (d) erosion at Lesišćina.

the following mineralogical composition of the samples (Table 1) was identified: calcite (35-50\%), quartz (5-10\%), plagioclase (up to $10 \%$ ), K-feldspar (trace), and clay minerals (40-55\%). Calcite, quartz, and phyllosilicates make up 93$97 \%$ of the mineralogical composition of the siltstones, and phyllosilicates are the prevalent minerals. The major clay minerals are illite and chlorite, and trace amounts of kaolinite and mixed-layer minerals are present. The different weathering grades of the siltstones in the study area have different mineralogical contents. The clay mineral content of the siltstones increases and the calcite content decreases with increasing weathering grade. The proportions of particular clay minerals, such as chlorite and illite, also increase with increasing weathering grade.

\section{Test Methods}

The scope of this study is to discuss and identify changes in the geotechnical properties and durability of siltstones due to long-term weathering processes that affect landslide reactivation. Siltstone samples of different weathering grades that were taken from flysch rock masses were subjected to laboratory testing to obtain data about their geotechnical and 


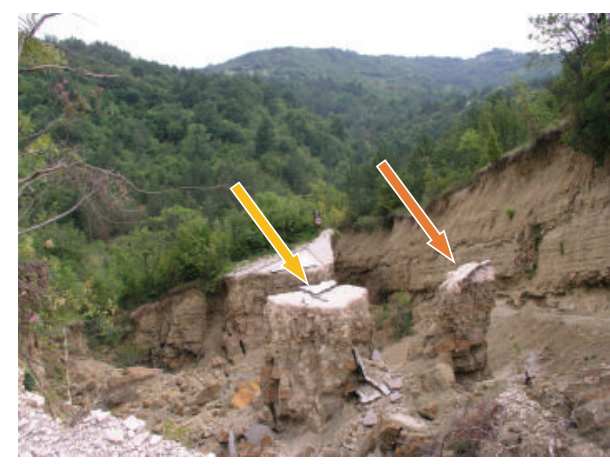

(a)

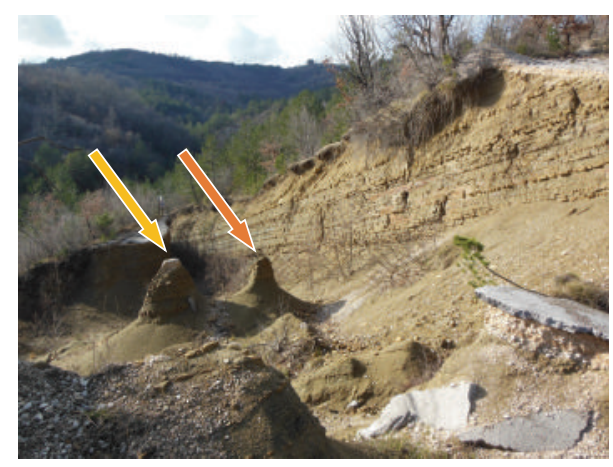

(b)

Figure 4: View of a landslide body and lateral scarp from the crown of the Brus Landslide in (a) August 2005 and (b) January 2013.

TABLE 1: Mineralogical compositions of siltstone samples of different weathering grades [30].

\begin{tabular}{lccccccccc}
\hline Sample & Calcite & Quartz & Plagioclase & K-feldspar & Illite & Chlorite & Kaolinite & Mixed-layer clay minerals & Total clay minerals \\
\hline FR & 50 & $\sim 5$ & $<5$ & - & $15-20$ & 21 & $*$ & - & $\sim$ \\
SW & 45 & $\sim 5$ & $5-10$ & - & $15-20$ & 20 & $*$ & $*$ & $\sim 40$ \\
CW & 35 & $5-10$ & $5-10$ & $*$ & $\sim 25$ & 22 & $*$ & $*$ & $\sim 50$ \\
RS & 37 & $5-10$ & $5-10$ & - & $\sim 30$ & 24 & $*$ & $* *$ & $\sim 55$ \\
\hline
\end{tabular}

— indicates no presence of minerals.

${ }^{*}$ Minerals in traces.

** Small amount of minerals.

durability characteristics. Details about the methodology that was used are described in the following paragraphs.

4.1. Geotechnical Properties of Siltstones. Four representative samples of siltstone of different weathering grades, including I (FR), II (SW), III (MW), and V (CW), were collected from a flysch outcrop near Cunj Village in Istria and crumbled before laboratory testing. The siltstone samples of different weathering grades were disturbed and remolded to the engineering soil grade. The state of these siltstone samples matches the material state at the sliding surface, where natural disintegration of the siltstone occurs due to stresses and strains that are caused by sliding. The following geotechnical properties of the treated samples were determined: the grain size distribution according to the ASTM standard D691304 [31], the specific gravity of the soil particles following the ASTM standard C188-15 [32], and the Atterberg limits according to the ASTM D4318-10e1 standard [33] and according to British Standards BS1377-2:1990 [34]. The test results of siltstone samples of different weathering grades were compared with the changes of the geotechnical properties of sedimentary rocks due to weathering that were investigated by other researchers (e.g., $[3,6])$. The decrease in durability of the flysch rock mass is responsible for slope stability problems due to the rapid disintegration and loss of shear strength. Eberhardt et al. [35] and Miščević et al. [36] used numerical analyses to demonstrate that landslides occur through beds of weathered marls due to the degradation of shear strength as a result of weathering and saturation of the rock mass by heavy precipitation. Vivoda Prodan et al. [30] determined changes in the residual shear strength due to weathering based on tests using ring shear and direct shear devices. The measured residual friction angle increases and the residual cohesion decreases with increasing weathering grade of siltstone samples.

4.2. Point Load Test. The point load test (PLT) was used to determine the strength of the siltstone samples of different weathering grade. Tests were performed on siltstone samples of weathering grades I (FR) and III (MW) from the outcrops near Cunj Village and Sovinjak Village in Istria (Figures 1 and 5). The load was applied normal to bedding (perpendicular to any discontinuities) of irregular block samples immediately after sampling to avoid further weathering and resulting strength reduction. The point load strength index, $I_{s(50)}$, is calculated using

$$
I_{s(50)}=I_{s} \times F=\left(\frac{P}{D_{e}^{2}}\right) \times F,
$$

where $P$ is the load on the point, $D_{e}$ is the equivalent core diameter calculated from expression (2), and $F$ is size correction factor given by (3):

$$
\begin{aligned}
D_{e}^{2} & =\frac{(4 \times W \times D)}{\pi}, \\
F & =\left(\frac{D_{e}}{50}\right)^{0.45} .
\end{aligned}
$$

The mean value of $I_{s(50)}$ is calculated by deleting the two highest and lowest values from the 10 valid tests and calculating the mean of the remaining values. The uniaxial compressive 


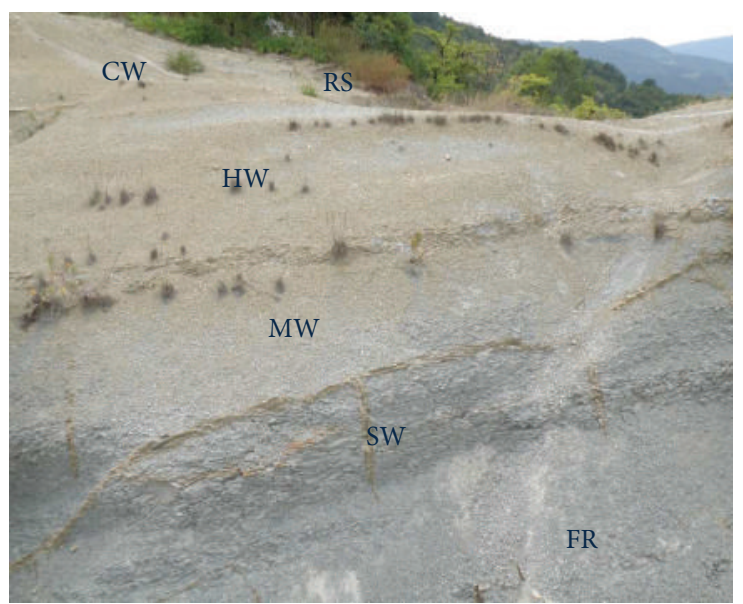

(a)

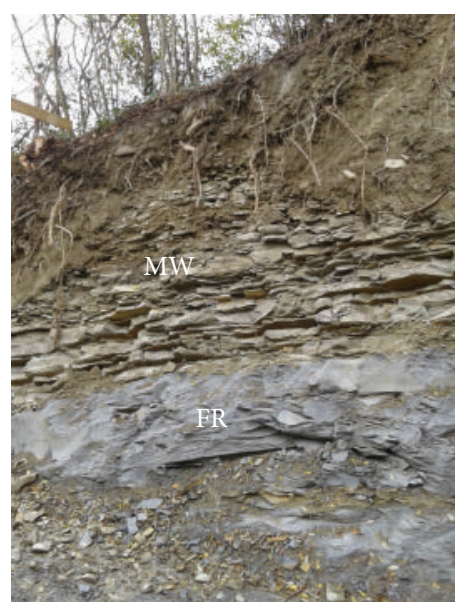

(b)

FIGURE 5: Locations of samples that were collected for laboratory testing from flysch outcrops near (a) Cunj Village and (b) Sovinjak Village.

strength of an intact siltstone sample is 24 times point load strength index [25]. The test was performed according to the standards that were proposed by ISRM [37]. The values of the uniaxial compressive strength that were obtained from the PLTs were compared with results from siltstone samples from the Istria Peninsula that were presented by other authors (e.g., $[25,38])$.

4.3. Slake Durability Test and Fragment Size Distribution Analysis. The natural conditions of repeated drying and wetting over long periods of time affected the flysch rock and caused signs of weathering and degradation in the outcrop samples. The slake durability test was used to investigate the weathering resistance (i.e., the durability) of the rocks. The tests were performed on siltstone samples of weathering grades I (FR) and III (MW) that were collected from outcrops near Cunj Village and Sovinjak Village in Istria (Figures 1 and 5). The slake durability test was performed in accordance with the [16] standard procedure in five drying-wetting cycles. Ten $45-55 \mathrm{~g}$ pieces of intact siltstone were prepared, which resulted in a total sample mass of $470-500 \mathrm{~g}$. The samples were dried for 24 hours in an oven at $105^{\circ} \mathrm{C}$, sieved, and then subjected to rotation in a standard slake durability test apparatus for 10 minutes. This procedure was repeated for all five cycles. In addition to the standardized determination of the slake durability index, $I_{d 2}$, the nature of the slaked material that is retained in the drum after each cycle of slake durability test must be quantitatively analyzed. Therefore, the fragment size distribution was used to better define the slaking characteristics of the tested flysch rock samples. The grain size distribution was determined after each dryingwetting cycle. The sieves that were used for the fragment size distribution had aperture sizes of 50, 37.5, 31.5, 28, 20, 14, $10,6.3,5$, and $2 \mathrm{~mm}$. Fragment size distribution curves after each of the five test cycles were plotted with the percents passing and retained (by weight) on the $y$-axis. After each cycle, the slake durability index $\left(\mathrm{I}_{d}\right)$ was calculated, and the values were compared with the results of two cycles of tests on similar sedimentary rocks in Croatia (e.g., [25, 39]). The disintegration ratio $\left(D_{R}\right)$ and the modified disintegration ratio $\left(D_{R P}\right)$ were also determined to better define the slaking behavior. The disintegration ratio is defined as the ratio of the area under the fragment size distribution curve of the retained fragments to the total area that encompasses the range of fragment size distributions [12]. $D_{R}$ is equal to 0 for nondurable rocks and to 1 for completely durable rocks. The modified disintegration ratio is a similar parameter and it is equal to the ratio of the area under the fragment size distribution curve of the passed fragments to the total area that encompasses the range of fragment size distributions [18]. Different graphs are used to determine these parameters, so $D_{R P}$ is equal to 1 for the maximum degree of degradation. A rock with a $D_{R}$ value close to 1 and a $D_{R P}$ value close to 0 will not only exhibit high durability in the field but also not disintegrate into smaller fragments.

\section{Test Results}

Laboratory tests were conducted to investigate the variability in the geotechnical parameters and the durability of the siltstone samples of different weathering grades. The silt and clay contents vary from $20 \%$ in the sample of weathering grade $\mathrm{V}(\mathrm{CW})$ to $31 \%$ for weathering grade I (FR). The plastic limits of the samples are between 24 and $28 \%$ and are not related to the weathering grade. The liquid limits increase with increasing weathering grade. The values that were obtained with the Casagrande device vary between 33\% for the sample of weathering grade I (FR) and $43 \%$ for weathering grade $\mathrm{V}(\mathrm{CW})$, and those from the fall cone test vary from $31 \%$ for weathering grade I (FR) to $40 \%$ for weathering grade $\mathrm{V}(\mathrm{CW})$. There is a good correlation $(0.8882)$ between the liquid limits that were determined with the two tests so both test results can be considered to be relevant. The plasticity index increases with increasing weathering grade from $4 \%$ for weathering grade I (FR) to $12 \%$ for weathering grade V (CW). The plasticity indexes are low, and the samples are classified 
TABLE 2: Geotechnical properties of the siltstone samples of different weathering grades.

\begin{tabular}{|c|c|c|c|c|c|c|c|c|c|}
\hline \multirow{3}{*}{$\begin{array}{l}\text { Weathering } \\
\text { grade }\end{array}$} & \multirow{3}{*}{$\begin{array}{l}\text { Sampling } \\
\text { location }\end{array}$} & \multicolumn{3}{|c|}{$\begin{array}{l}\text { Grain size analysis [\%] } \\
{[30]}\end{array}$} & \multirow{3}{*}{$\begin{array}{l}\text { Plastic limit } \\
\qquad\left(w_{P}\right)\end{array}$} & \multicolumn{2}{|c|}{ Atterberg limits [\%] } & \multirow{3}{*}{$\begin{array}{l}\text { Plasticity } \\
\text { index (PI) }\end{array}$} & \multirow{3}{*}{$\begin{array}{c}\text { Specific gravity } \\
{\left[\mathrm{g} / \mathrm{cm}^{3}\right][30]} \\
\left(G_{s}\right)\end{array}$} \\
\hline & & \multirow{2}{*}{ Sand (S) } & \multirow{2}{*}{ Silt (M) } & \multirow{2}{*}{ Clay (C) } & & \multicolumn{2}{|c|}{ Liquid limit $\left(w_{L}\right)$} & & \\
\hline & & & & & & $\begin{array}{c}\text { Casagrande } \\
\text { device }\end{array}$ & $\begin{array}{l}\text { Fall cone } \\
\text { test }\end{array}$ & & \\
\hline I (FR) & \multirow{4}{*}{ Cunj } & 69 & 20 & 11 & 27 & 33 & 31 & 4 & 2.65 \\
\hline II (SW) & & 80 & \multicolumn{2}{|c|}{20} & 23 & 34 & 28 & 5 & - \\
\hline III (MW) & & 75 & 15 & 10 & 24 & 35 & 32 & 8 & 2.62 \\
\hline $\mathrm{V}(\mathrm{CW})$ & & 80 & 13 & 7 & 28 & 43 & 40 & 12 & 2.58 \\
\hline
\end{tabular}

as ML in the plasticity chart. The specific gravity values vary from 2.58 to $2.65 \mathrm{~g} / \mathrm{cm}^{3}$.

Chandler [3] estimated typical index properties of four weathering stages of Keupler marl and found little difference between the index properties of marls from the unweathered zone I and the partially weathered zones II and III. The fully weathered zone IV was considerably plastic. The influence of weathering on the properties of mudstone was investigated by Bhattarai et al. [6] and they concluded that there is no significant difference in the consistency limits of the soil and rock samples with depth. Table 2 shows the results of the geotechnical properties of the siltstone samples of different weathering grades.

The PLT and the Schmidt hammer test can be applied to siltstone samples of weathering grades I (FR), II (SW), and III (MW). These tests resulted in different uniaxial compressive strengths for the samples of different weathering grades. The uniaxial compressive strengths from the Schmidt hammer rebound values are $22 \mathrm{MPa}$ for sample of weathering grade III (MW), $33 \mathrm{MPa}$ for weathering grade II (SW), and $55 \mathrm{MPa}$ for weathering grade I (FR). Similar values of the uniaxial compressive strength were obtained from the PLTs, including $19 \mathrm{MPa}$ for the sample of weathering grade III (MW) and $48 \mathrm{MPa}$ for weathering grade I (FR). Acceptable values of the uniaxial compressive strength from these two tests must be based on the statistical mean from numerous tests excluding extreme values. The disadvantage of the PLT is the large dispersion of the results, which especially occurs in weak rock masses such as flysch. This dispersion is caused by the layers of the rock mass layers, the layer orientation during sampling, the sample size, and the weathering of the rock mass. However, regardless of its disadvantages, the PLT method is recommended when there is a lack of more reliable tests, where there is a lack of appropriate representative samples, and when it can be used in combination with detailed descriptions of tested samples from the rock mass. Table 3 provides descriptions, typical characteristics, and characteristic uniaxial strength values for the different weathering grades of siltstones. Žufić [25] conducted in situ PLT tests on similar materials, and the point compressive strengths varied from 8 to $36 \mathrm{MPa}$. Arbanas et al. [38] presented results of PLTs of flysch siltstone samples of different weathering grades. The results from fresh siltstone samples corresponded to uniaxial strengths of 10 to $15 \mathrm{MPa}$ and a maximum of $20 \mathrm{MPa}$. The corresponding uniaxial strengths of moderate to slightly weathered samples were less than $2 \mathrm{MPa}$; these values are not confident and are unacceptable for use in engineering analyses without adequate precautions.

Gamble [8] suggested that slake durability index values that are taken after three or more cycles of slaking and drying may be useful for evaluating rock durability. The slaking behavior of siltstones cannot be described adequately using only two cycles and only a single aperture, such as the $2 \mathrm{~mm}$ mesh drum that is used in the standardized slake durability test. Therefore, in this study, 5 cycles were applied to each sample, and the fragment size distribution approach was used to better define the slaking characteristics of the tested siltstones. Figure 6 shows the fractions of the tested samples that were retained in the test drum for the initial conditions and after the second and fifth cycles.

The samples that were retained in the drum were extremely fragmented and appeared highly degraded (Figure 7). However, the fragments were larger than $2 \mathrm{~mm}$, which led to the high $\mathrm{I}_{d 2}$ values. However, high $\mathrm{I}_{d 2}$ values do not correlate with this highly degraded state. Therefore, the fragment size distribution of the fragmented siltstone that was retained in the drum after each cycle of the slake durability test was quantified.

Figure 8 shows the fragment size distribution curves of the retained weight, and Figure 9 shows fragment size distribution curves of the passed weight through all of the cycles of the slake durability test of siltstone samples of weathering grades I (FR) and III (MW) that were collected from flysch outcrops near Cunj Village and Sovinjak Village. The fragment size distribution curve of the retained fragments is required to define the disintegration ratio after each of the five cycles of the slake durability test. The modified degradation ratio after each cycle is also determined based on the fragment size distribution curve of the passed fragments of the sample. The slake durability index, disintegration ratio, and modified disintegration ratio after each of the five cycles are presented in Table 4.

Figure 10 shows the number of cycles plotted against the slake durability index. According to the classification of Gamble [8], the samples from the Cunj outcrop can be categorized as highly durable rocks. The $\mathrm{I}_{d 2}$ values for the siltstone sample of weathering grade I (FR) range from 97.03 to $97.82 \%$, and the $I_{d 5}$ values range from 94.01 to $94.24 \%$. The $\mathrm{I}_{d 2}$ values for the siltstone sample of weathering grade III 


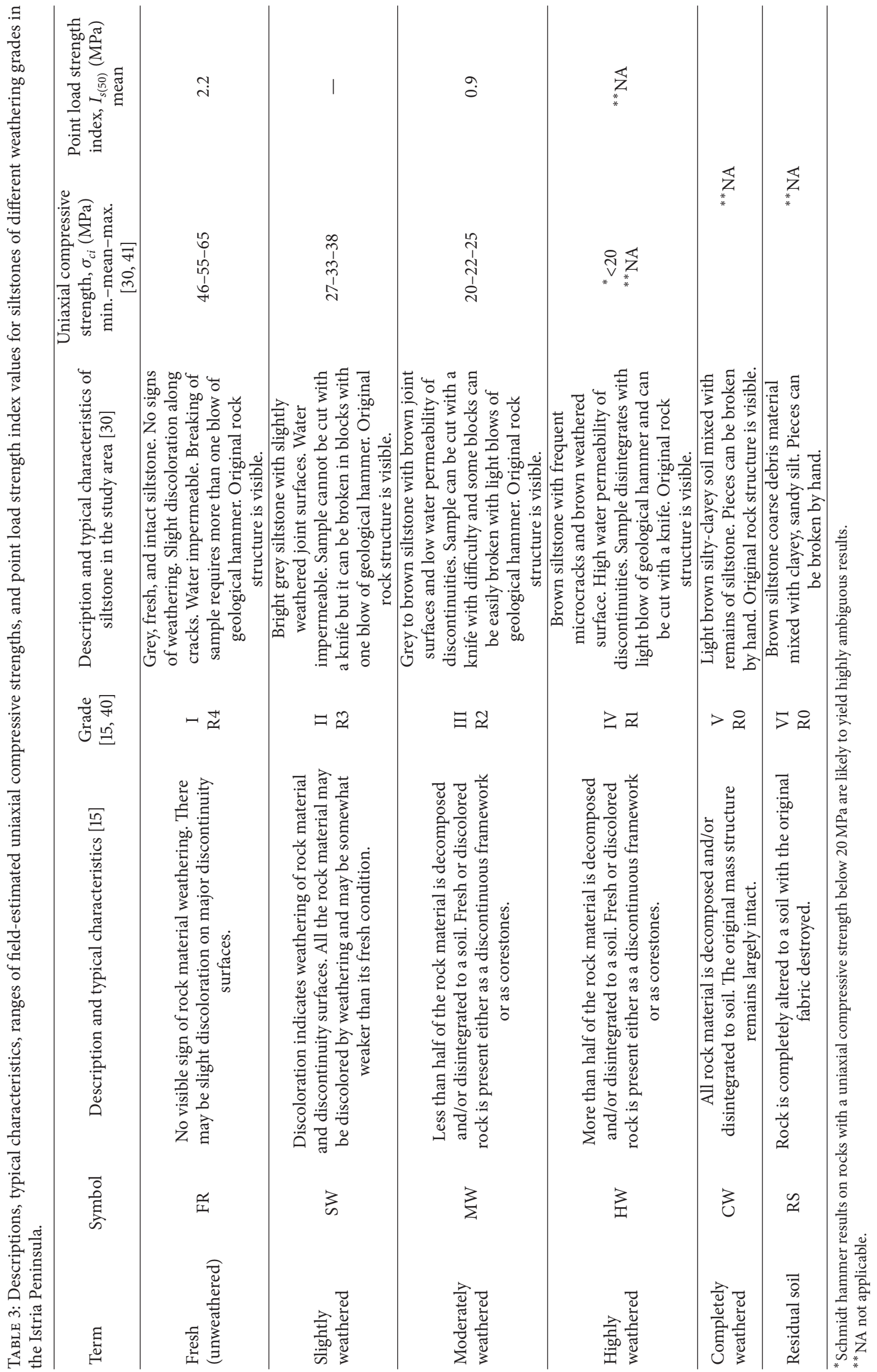



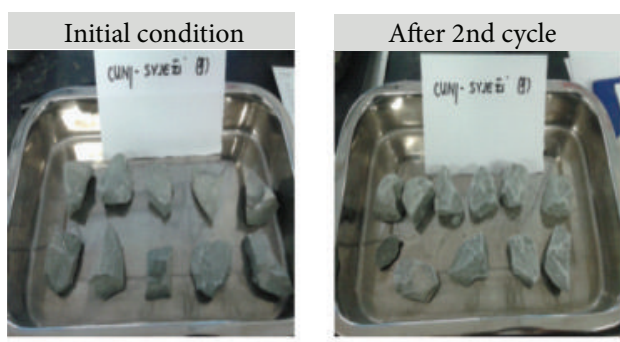

(a)
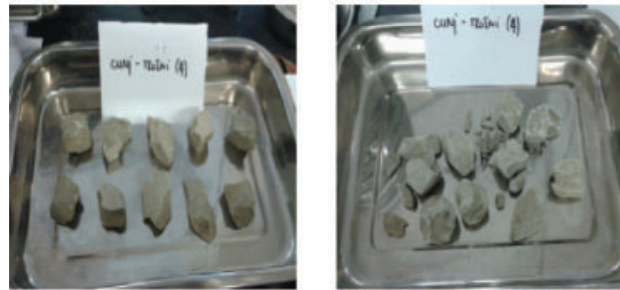

(b)

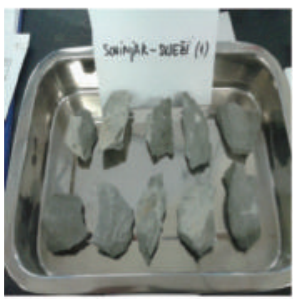

$\int_{1}$

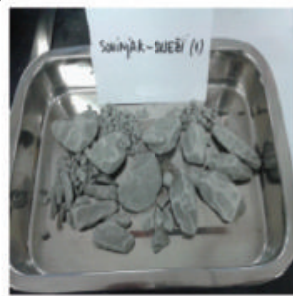

(c)
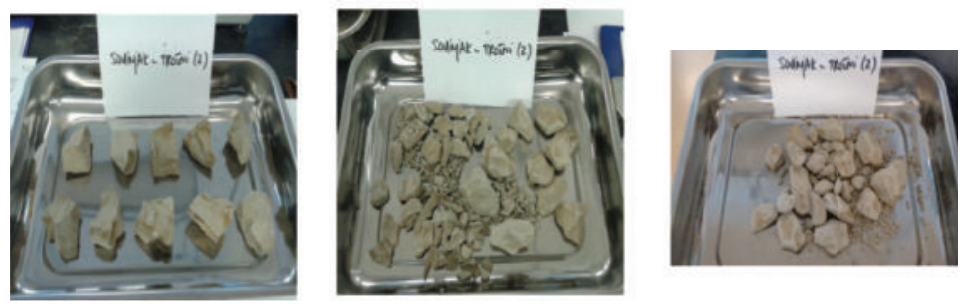

(d)

FIGURE 6: Samples taken from flysch outcrops near ((a), (b)) Cunj Village and ((c), (d)) Sovinjak Village, including initial conditions (left), after the 2 nd cycle (middle), and after the 5th cycle (right) of the slake durability test.

(MW) range from 95.39 to $97.73 \%$, and the $\mathrm{I}_{d 5}$ values range from 89.52 to $94.45 \%$. The samples from the Sovinjak outcrop are categorized as medium to highly durable rocks with $\mathrm{I}_{d 2}$ values of $88.31 \%$ for the siltstone sample of weathering grade I (FR) and $89.69 \%$ for the sample of weathering grade III (MW). The slake durability indexes of the samples from the Sovinjak outcrop decrease significantly from the second cycle to the fifth cycle. The sample of weathering grade I (FR) has a lower durability index after each cycle than the sample of weathering grade III (MW). Based on a visual inspection and the conditions after the second cycle, the samples should be categorized as a lower class in Gamble's classification.

Žufić [25] performed two cycles of slake durability tests on fresh siltstones from flysch badlands in the Istria Peninsula. The slake durability index after the second cycle varied from 94.17 to $99.09 \%$. These results are quite similar to those that were obtained from siltstone samples from the Cunj outcrop in this study. Further sample degradation cannot be compared because [25] performed only two slaking cycles. Vlastelica [39] investigated the durability of marls from a flysch rock mass in the Dalmatia region of Croatia through four cycles of slake durability tests. The slake durability index varied from 97.31 to $99.29 \%$ after the second cycle and from 94.39 to $98.27 \%$ after the fourth cycle. These results are higher than the results that were obtained in this study probably because the mineral composition and textural features of the marls in the Dalmatia region are different than those in this study. Figure 10 shows the relationship between the slake durability index and the number of slaking cycles in this study and in previous investigations of similar sedimentary rocks. However, when they are subjected to the slake durability test, siltstone samples disintegrate to fragments of different 


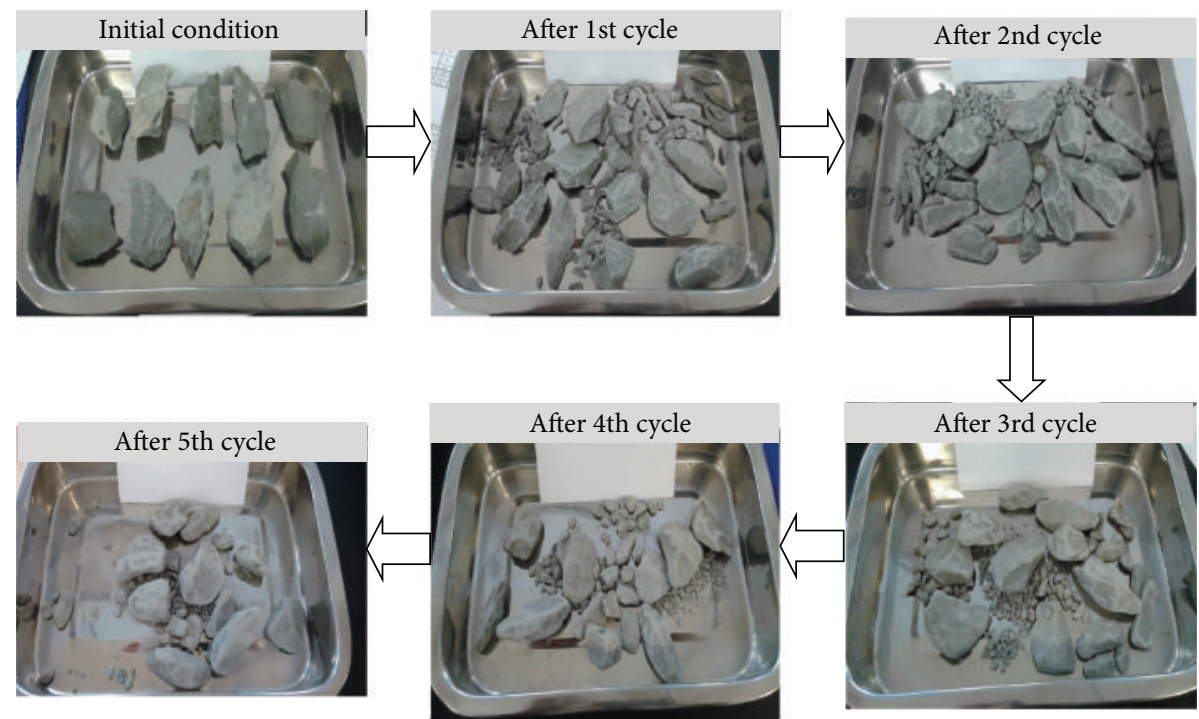

FIGURE 7: Example of a heavily degraded siltstone sample of weathering grade I (FR) (1) taken from a flysch outcrop near Sovinjak Village after five cycles of the slake durability test with $\mathrm{I}_{d 2}=88 \%$ and $\mathrm{I}_{d 5}=73 \%$.

TABLE 4: Results of five cycles of the slake durability tests, including the slake durability index, degradation ratio, and modified degradation ratio, for siltstones of different weathering grades in the study area.

\begin{tabular}{|c|c|c|c|c|c|c|c|}
\hline Weathering grade & Sample number & Sampling location & First cycle & Second cycle & Third cycle & Fourth cycle & Fifth cycle \\
\hline & & & \multicolumn{5}{|c|}{ Slake durability index $\left(I_{d}\right)$} \\
\hline & & \multirow{3}{*}{ Sovinjak } & $\mathrm{I}_{d_{1}}[\%]$ & $\mathrm{I}_{d_{2}}[\%]$ & $\mathrm{I}_{d_{3}}[\%]$ & $\mathrm{I}_{d_{4}}[\%]$ & $\mathrm{I}_{d_{5}}[\%]$ \\
\hline $\mathrm{I}(\mathrm{FR})$ & $(1)$ & & 94.71 & 88.31 & 82.16 & 76.75 & 72.60 \\
\hline III (MW) & $(2)$ & & 94.35 & 89.69 & 85.34 & 80.97 & 76.75 \\
\hline I (FR) & (3) & \multirow{4}{*}{ Cunj } & 98.15 & 97.03 & 95.99 & 94.96 & 94.01 \\
\hline III (MW) & $(4)$ & & 97.41 & 95.39 & 93.40 & 91.45 & 89.52 \\
\hline $\mathrm{I}(\mathrm{FR})$ & $(5)$ & & 98.76 & 97.82 & 96.41 & 95.51 & 94.24 \\
\hline \multirow[t]{3}{*}{ III $(\mathrm{MW})$} & (6) & & 98.64 & 97.73 & 96.32 & 95.52 & 94.45 \\
\hline & & & \multicolumn{5}{|c|}{ Degradation ratio $\left(D_{R}\right)$} \\
\hline & & \multirow{3}{*}{ Sovinjak } & $D_{R 1}$ & $D_{R 2}$ & $D_{R 3}$ & $D_{R 4}$ & $D_{R 5}$ \\
\hline $\mathrm{I}(\mathrm{FR})$ & (1) & & 0.69 & 0.65 & 0.61 & 0.58 & 0.55 \\
\hline III (MW) & (2) & & 0.69 & 0.60 & 0.56 & 0.53 & 0.50 \\
\hline I (FR) & (3) & \multirow{2}{*}{ Cunj } & 0.84 & 0.81 & 0.79 & 0.78 & 0.76 \\
\hline \multirow[t]{3}{*}{ III $(\mathrm{MW})$} & (4) & & 0.82 & 0.79 & 0.75 & 0.72 & 0.69 \\
\hline & & & \multicolumn{5}{|c|}{ Modified degradation ratio $\left(D_{R P}\right)$} \\
\hline & & \multirow{3}{*}{ Sovinjak } & $D_{R P 1}$ & $D_{R P 2}$ & $D_{R P 3}$ & $D_{R P 4}$ & $D_{R P 5}$ \\
\hline I (FR) & (1) & & 0.30 & 0.35 & 0.39 & 0.42 & 0.50 \\
\hline III (MW) & (2) & & 0.31 & 0.41 & 0.45 & 0.47 & 0.50 \\
\hline I (FR) & (3) & \multirow{2}{*}{ Cunj } & 0.16 & 0.20 & 0.21 & 0.22 & 0.24 \\
\hline III (MW) & (4) & & 0.18 & 0.22 & 0.25 & 0.28 & 0.31 \\
\hline
\end{tabular}

sizes that do not correspond to the high values of the slake durability index. The graphs in Figures 8 and 9 are used to calculate the degradation ratio and the modified degradation ratio after each slaking cycle (Table 4). Figure 11 shows the changes of these parameters through the slaking cycles. After each cycle, the siltstone sample of weathering grade I (FR) that was taken from the Sovinjak outcrop had a lower durability index than the sample of weathering grade III (MW). The other two parameters indicate that the siltstone sample of weathering grade III (MW) disintegrated more than the sample of weathering grade I (FR). According to the classification of Erguler and Shakoor [12], based on the disintegration ratio, the samples from the Cunj outcrop can be categorized as medium to highly durable rocks, and the samples from the Sovinjak outcrop can be categorized as medium durability rocks. Therefore, the tested samples are classified in the lower durability class based on the fragmentation during the slake durability test. 


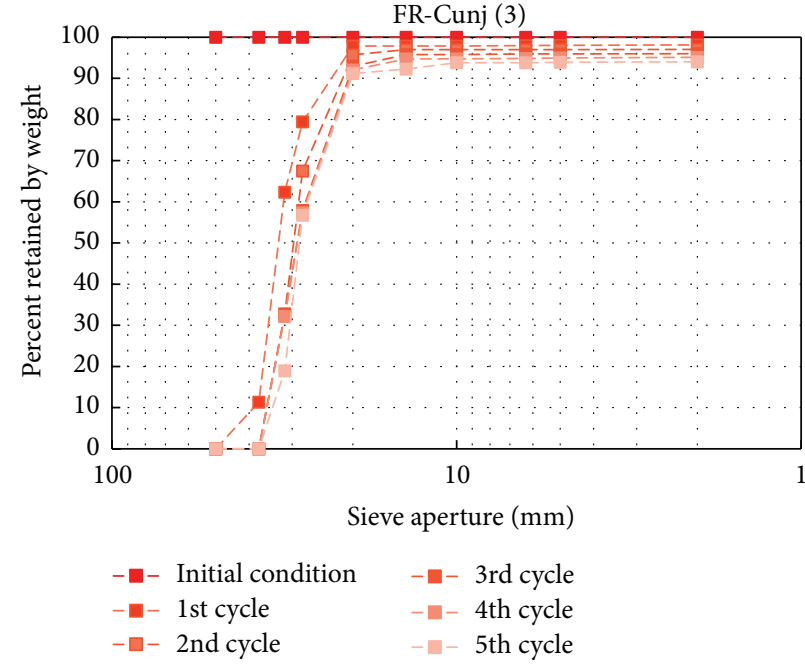

(a)

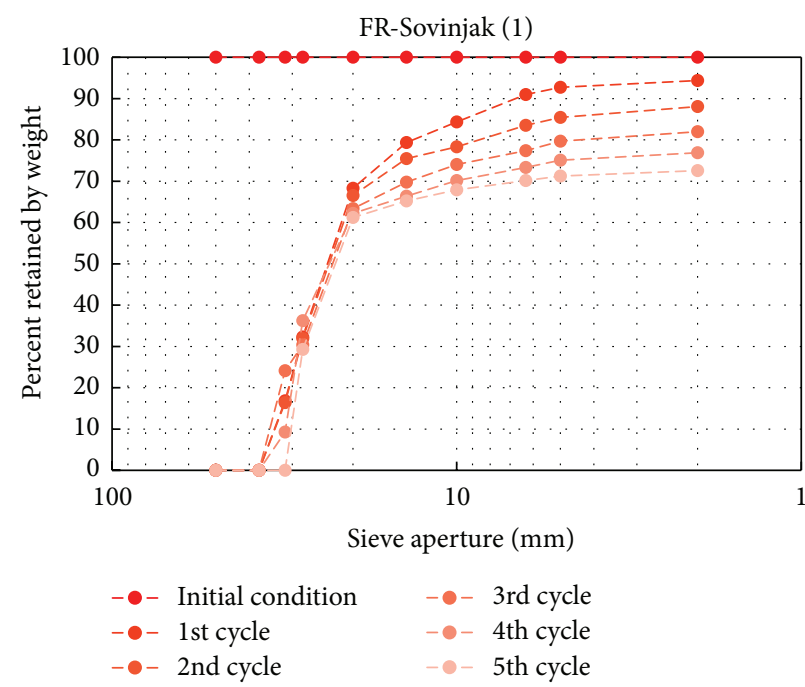

(c)

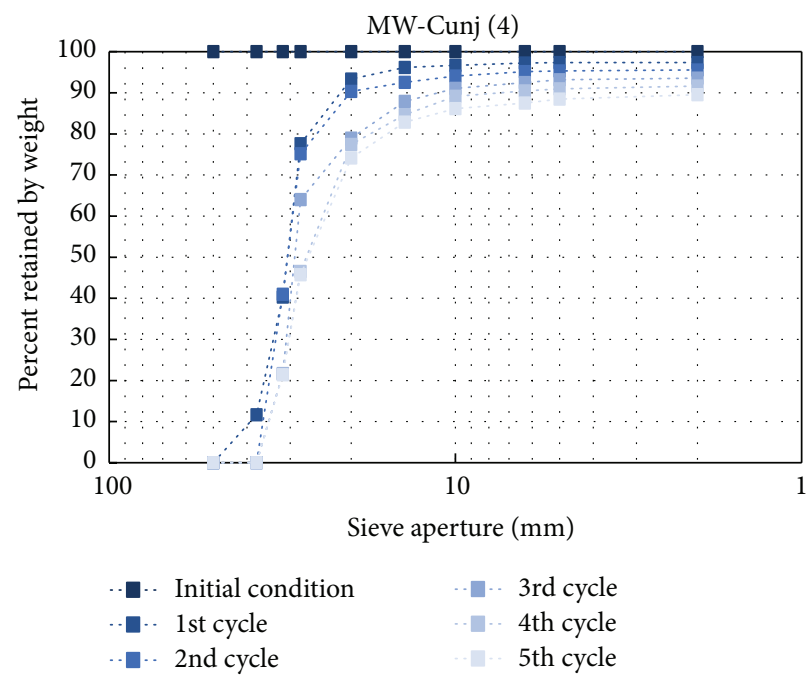

(b)

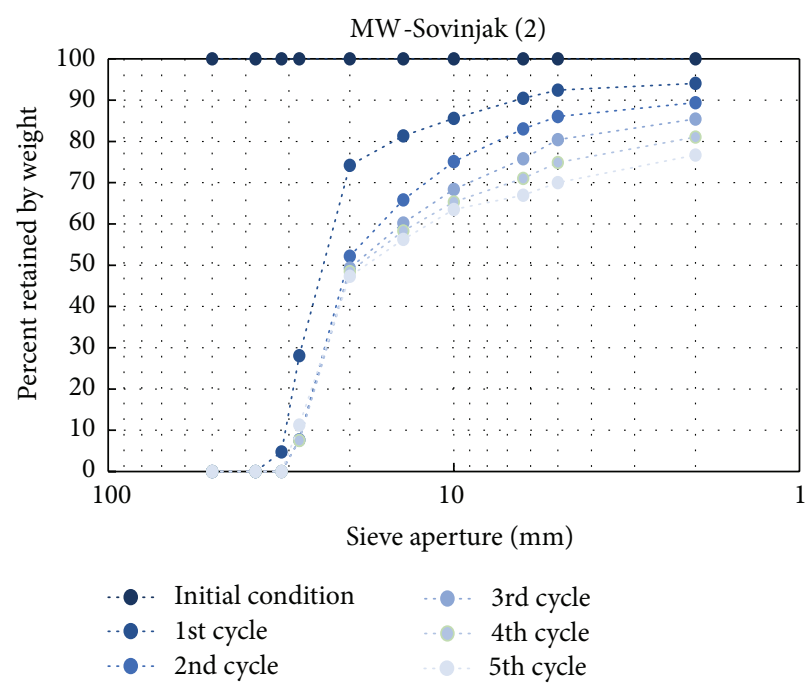

(d)

FIGURE 8: Fragment size distribution curves of the retained weight for the siltstone samples of weathering grades (a) I (FR) (3) and (b) III (MW) (4) from a flysch outcrop near Cunj Village and samples of weathering grades (c) I (FR) (1) and (d) III (MW) (2) from a flysch outcrop near Sovinjak Village.

The change in the calculated $D_{R P}$ values between the slaking cycles is also determined to assess the potential longterm degradation of the investigated samples. A logarithmic curve is fitted to the $D_{R P}$ values of each sample, and high $R^{2}$ values are calculated (Figure 12). From this curve, the number of cycles that are required for a sample to reach $50 \%$ of the maximum possible degradation $\left(D_{R P}=1\right), N_{50}$, is estimated. The siltstone samples from the Sovinjak outcrop are less durable and more susceptible to degradation than those from the Cunj outcrop, and the $N_{50}$ values differ considerably for the same weathering grade. The $N_{50}$ values for the samples from the Sovinjak outcrop are 9 cycles for the sample of weathering grade I (FR) and 5 cycles for the sample of weathering grade III (MW). The samples from the Cunj outcrop have $N_{50}$ values of 1050 cycles for weathering grade I (FR) and 60 cycles for weathering grade III (MW).

\section{Discussion and Conclusions}

The primary intent of this research is to establish relationship of geotechnical properties and durability with weathering of siltstones from a flysch rock mass in the Istria Peninsula. According to the results obtained by this study, weathering has a significant influence on the plasticity of siltstones. The liquid limit and plasticity index values of silty material increase with increasing weathering grade.

Weathering also has an influence on the uniaxial compressive strengths that are determined with a Schmidt hammer and the PLT. The uniaxial compressive strength decreases with increasing weathering grade. These test methods cannot be applied to highly weathered and more weathered siltstones that have uniaxial compressive strengths of less than $20 \mathrm{MPa}$ because the tests are likely to yield ambiguous results. 


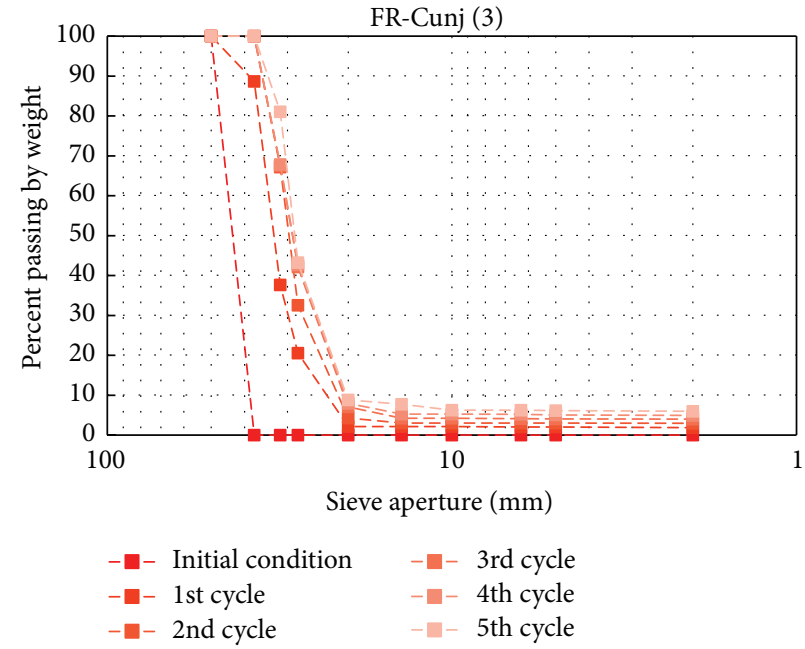

(a)

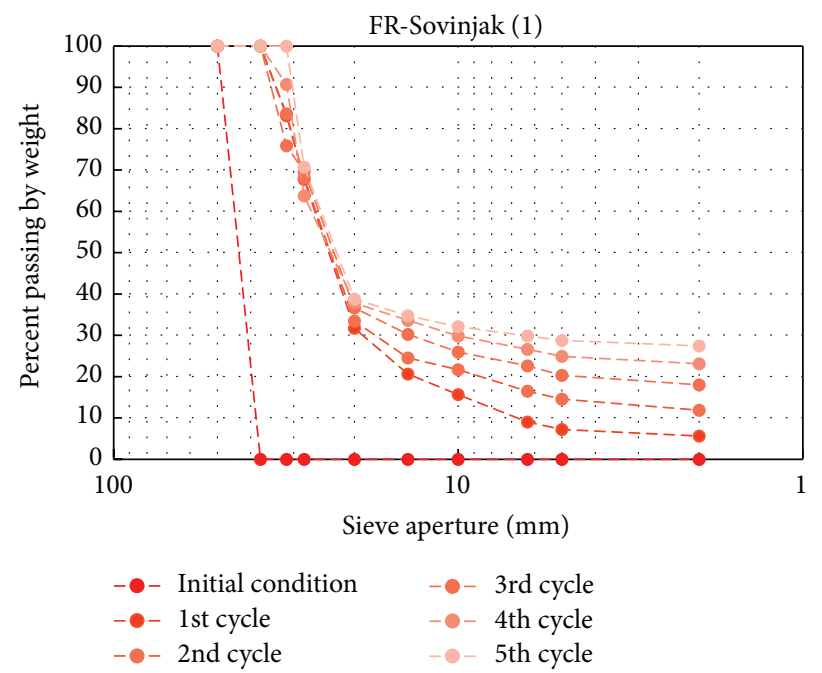

(c)

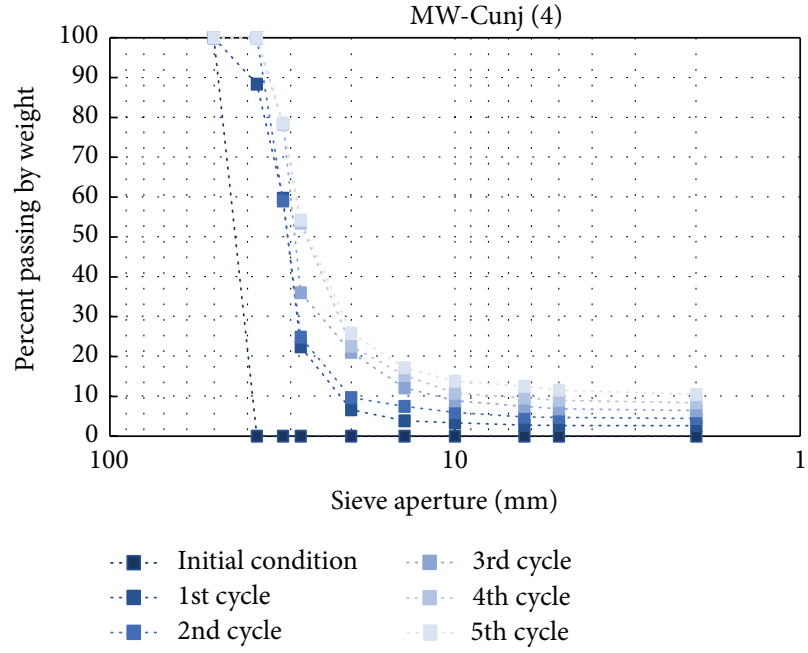

(b)

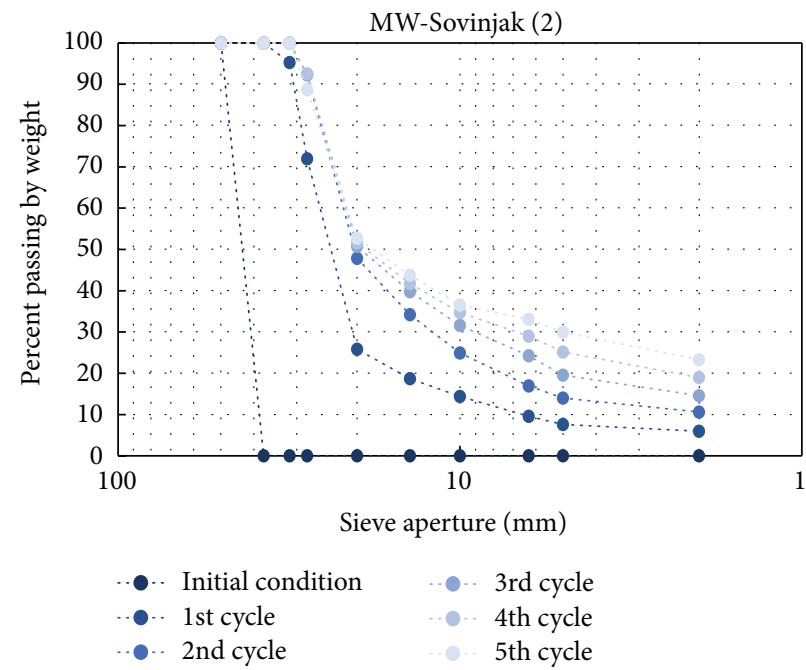

(d)

FIGURE 9: Fragment size distribution curves of the passed weight for the siltstone samples of weathering grades (a) I (FR) (3) and (b) III (MW) (4) from a flysch outcrop near Cunj Village and samples of weathering grades (c) I (FR) (1) and (d) III (MW) (2) from a flysch outcrop near Sovinjak Village.

Determination of durability of siltstones using only standardized tests is not sufficient. The use of the slake durability test does not adequately explain the slaking behavior of siltstones because the fragmented samples acquire high slake durability index but are highly degraded. Therefore, additional parameters, such as the degradation ratio and the modified degradation ratio, were calculated to indicate not only the durability but also the manner of disintegration of siltstones of different weathering grades. The siltstone sample of weathering grade I (FR) was more durable and less susceptible to degradation than the siltstone sample of weathering grade III (MW). Fresh samples disintegrated less than moderately weathered samples; therefore, fewer drying-wetting cycles are required to reach the maximum possible degradation. According to the classification based on the slake durability index the siltstone samples with different weathering grades from Istria are classified in the higher durability class than in classification based on the fragmentation during the slake durability test. The standard slake durability index increases the slaking resistance of the tested siltstone samples by at least one class.

The obtained laboratory results indicate that weathering has a significant influence on the plasticity, uniaxial compressive strength, and durability characteristics of the siltstones. Overall, these test results demonstrated their usefulness of understanding influence of weathering of siltstones from the flysch rock masses on the landslide and erosion occurrences in the Istria Peninsula. The authors suggest that additional tests and studies on siltstones with different weathering grades are needed to widen the obtained results. 


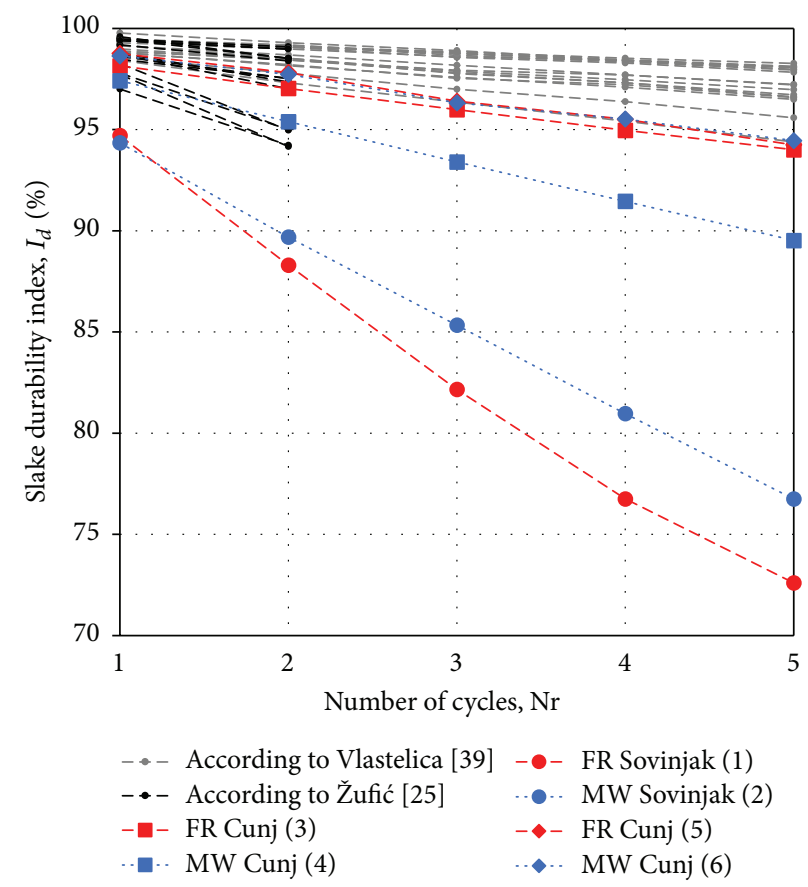

FIGURE 10: Influence of the number of slaking cycles on the slake durability index of the siltstone samples of different weathering grades that were tested in this study and from previous tests of similar samples of fresh siltstone from a flysch rock mass in Istria [25] and marl samples from a flysch rock mass in Dalmatia [39].

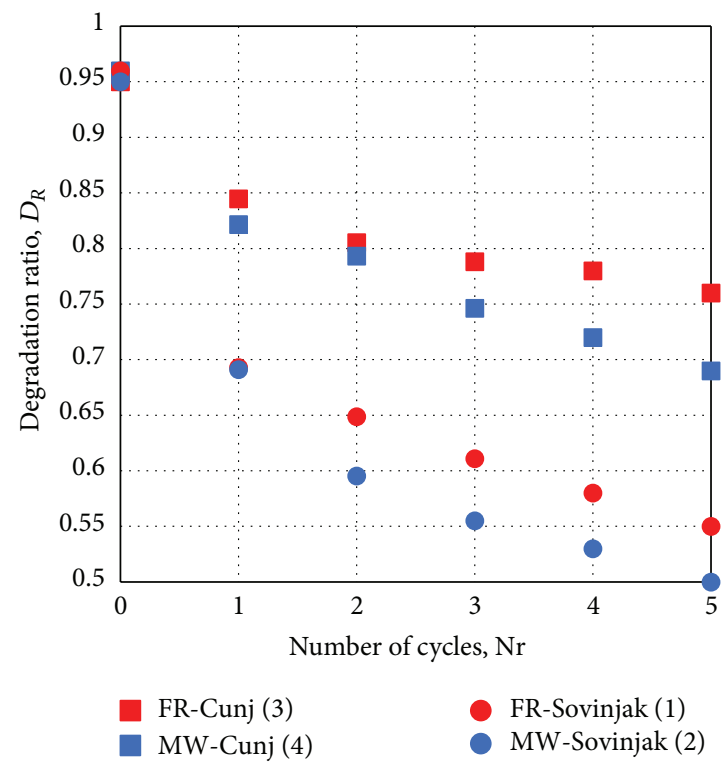

(a)

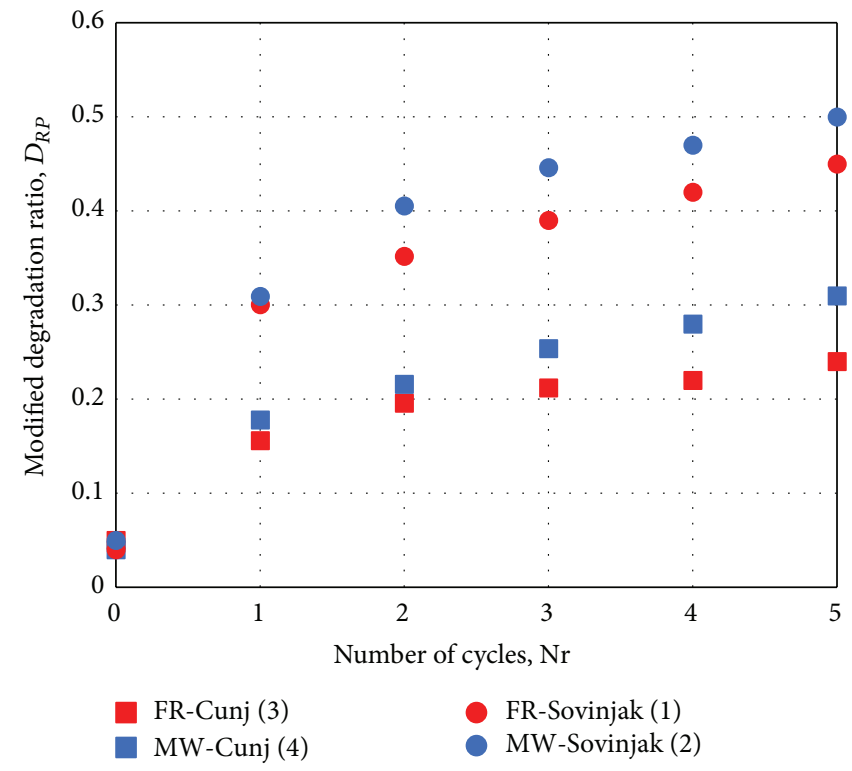

(b)

FIGURE 11: (a) Degradation ratio and (b) modified degradation ratio after each slaking cycle for the siltstone samples of weathering grades I (FR) and III (MW) from flysch outcrops near Cunj Village and Sovinjak Village.

\section{Competing Interests}

The authors declare that they have no competing interests.

\section{Acknowledgments}

This work has been supported in part by the University of Rijeka under Project no. 475, entitled Development of
Landslide Monitoring and Early Warning System for the Purpose of Landslide Hazard Reduction. As well, this work has been supported in part by Ministry of Science, Education and Sports of the Republic of Croatia under the project Research Infrastructure for Campus-Based Laboratories at the University of Rijeka, no. RC.2.2.06-0001. Project has been cofunded from the European Fund for Regional Development (ERDF). 


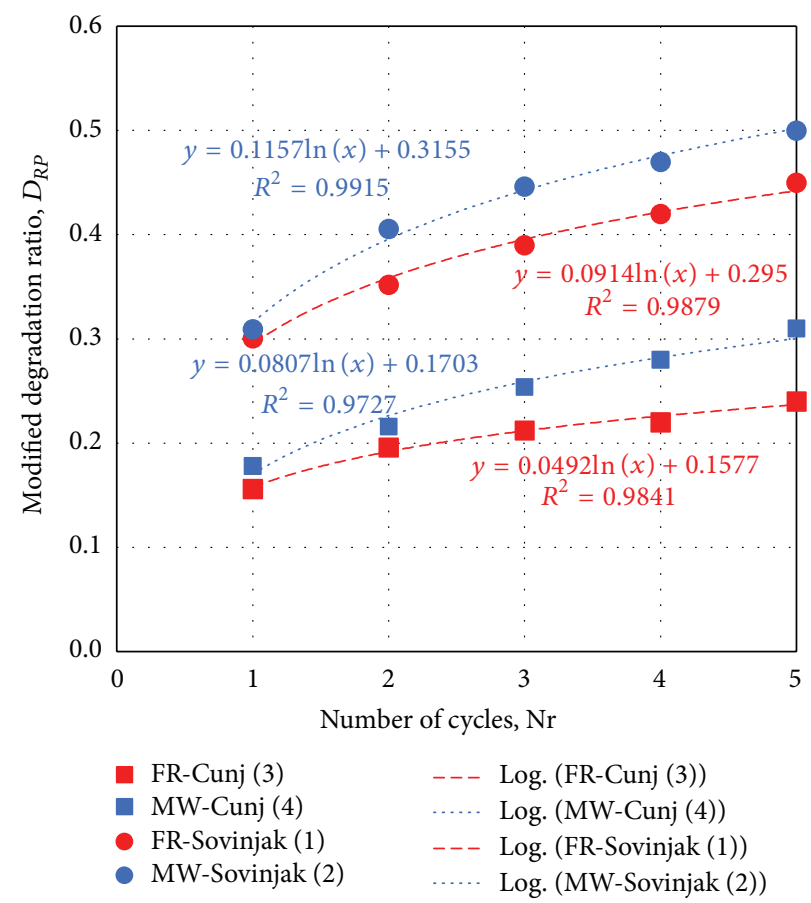

FIGURE 12: Logarithmic curves fitted to the plot of the modified degradation ratio against slake durability test cycles for the siltstone samples of weathering grades I (FR) and III (MW) from the flysch outcrops near Cunj Village and Sovinjak Village.

\section{References}

[1] M. J. Selby, Hillslope Materials and Processes, Oxford University Press, 1993.

[2] Geological Society of London, "The preparation of maps and plans in terms of engineering geology: report by the Geological Society Engineering Group Working Party," Quarterly Journal of Engineering Geology and Hydrogeology, vol. 5, no. 4, pp. 293382, 1972.

[3] R. J. Chandler, "The effects of weathering on the shear strength properties of Keupler marl," Geotehnique, vol. 19, no. 3, pp. 321334, 1969.

[4] M. Reißmüller, Geotechnische Eigenschaften verwitterter Kfssener Mergel [Diploma thesis], Technical University of Munich, Munich, Germany, 1997.

[5] M. Chigira and T. Oyama, "Mechanism and effect of chemical weathering of sedimentary rocks," Engineering Geology, vol. 55, no. 1-2, pp. 3-14, 2000.

[6] P. Bhattarai, H. Marui, B. Tiwari, N. Watanabe, G. Tuladhar, and K. Aoyama, "Influence of weathering on physical and mechanical properties of mudstone," in Disaster Mitigation of Debris Flows, Slope Failures and Landslides, pp. 467-479, Universal Academy Press, Tokyo, Japan, 2006.

[7] P. G. Fookes, C. S. Gourley, and C. Ohikere, "Rock weathering in engineering time," Quarterly Journal of Engineering Geology, vol. 21, no. 1, pp. 33-57, 1988.

[8] J. C. Gamble, Durability-plasticity classification of shales and other argillaceous rocks [Ph.D. thesis], University of Illinois, 1971.

[9] J. A. Franklin and R. Chandra, "The slake-durability test," International Journal of Rock Mechanics and Mining Sciences \& Geomechanics Abstracts, vol. 9, no. 3, pp. 325-328, 1972.

[10] J. C. Dick and A. Shakoor, "Characterizing durability of mudrocks for slope stability purposes," Geological Society of
America Reviews in Engineering Geology, vol. 10, pp. 121-130, 1995.

[11] J. Martinez-Bofill, J. Corominas, and A. Soler, "Behaviour of the weak rock cut slopes and their characterization using the results of the slake durability test," in Engineering Geology for Infrastructure Planning in Europe, vol. 104 of Lecture Notes in Earth Sciences, pp. 405-413, Springer, Berlin, Germany, 2004.

[12] Z. A. Erguler and A. Shakoor, "Quantification of fragment size distribution of clay-bearing rocks after slake durability testing," Environmental \& Engineering Geoscience, vol. 15, no. 2, pp. 8189, 2009.

[13] M. Cano and R. Tomás, "An approach for characterising the weathering behaviour of Flysch slopes applied to the carbonatic Flysch of Alicante (Spain)," Bulletin of Engineering Geology and the Environment, vol. 74, no. 2, pp. 443-463, 2015.

[14] Z. A. Erguler and R. Ulusay, "Assessment of physical disintegration characteristics of clay-bearing rocks: disintegration index test and a new durability classification chart," Engineering Geology, vol. 105, no. 1-2, pp. 11-19, 2009.

[15] ISRM Commision on Testing Methods, Rock Characterization, Testing and Monitoring: ISRM Suggested Methods, Pergamon Press, Oxford, UK, 1981.

[16] ASTM, "Standard test method for slake durability of shales and similar weak rocks," Tech. Rep. D4644-87, ASTM, Philadelphia, Pa, USA, 2004.

[17] P. Miščević and G. Vlastelica, "Durability characterization of marls from the region of dalmatia, croatia," Geotechnical and Geological Engineering, vol. 29, no. 5, pp. 771-781, 2011.

[18] M. Cano and R. Tomás, "Proposal of a new parameter for the weathering characterization of carbonate flysch-like rock masses: the Potential Degradation Index (PDI)," Rock Mechanics and Rock Engineering, vol. 49, no. 7, pp. 2623-2640, 2016. 
[19] I. Velić and I. Vlahović, Geologic Map of Republic of Croatia 1:300.000, Croatian Geological Survey, Zagreb, Croatia, 2009 (Croatian).

[20] S. Bergant, J. Tišljar, and M. Šparica, "Eocen carbonates and flysch deposits of the Pazin basin," in Field Trip Guidebook. 22nd IAS Meeting of Sedimentology, Institute of Geology, 2003.

[21] Ž. Arbanas, Č. Benac, and V. Jurak, "Causes of debris flow formation in flysch area of North Istria, Croatia," in Monitoring, Simulation, Prevention and Remediation of Dense and Debris Flows, G. Lorenzini and C. A. Brebbia, Eds., WIT Transaction on Ecology and the Environment, pp. 283-292, 2006.

[22] Ž. Arbanas, M. Grošić, D. Goršić, and B. Griparić, "Landslides remedial works on small roads of Istria," in Proceedings of the 4th Croatian Roads Congress, p. 38, 2007.

[23] Ž. Arbanas, S. Dugonjić, and Č. Benac, "Causes of small scale landslides in flysch deposits of Istria, Croatia," in Landslide Science and Practice, Volume 1: Landslide Inventory and Susceptibility and Hazard Zoning, C. Margottini, P. Canuti, and K. Sassa, Eds., pp. 221-226, Springer, Rome, Italy, 2013.

[24] Ž. Arbanas, S. Mihalić, M. Grošić, S. Dugonjić, and M. Vivoda, "Landslide brus, translational block sliding in flysch rock mass," in Proceedings of the European Rock Mechanics Symposium (EUROCK '10), pp. 635-638, June 2010.

[25] E. Žufić, Investigation of geotehnical properties offlysch rock mass in Istria area [M.S. thesis], University of Zagreb, 2011 (Croatian).

[26] V. Gulam, The erosion of flysch badlands in the central Istria [Ph.D. thesis], University of Zagreb, 2012 (Croatian).

[27] S. Utili, Evolution of natural slopes subject to weathering: an analytical and numerical study [Ph.D. thesis], Politecnico di Milano, Milan, Italy, 2004.

[28] R. Cardoso and E. E. Alonso, "Degradation of compacted marls: a microstructural investigation," Soils and Foundations, vol. 49, no. 3, pp. 315-327, 2009.

[29] D. Mihljević and E. Prelogović, "Structural—geomorphological characteristic of the mountain ranges Učka \& Ćićarija," in Proceedings of the International Symposium Geomorphology and Sea and the Meeting of the Geomorphological Commission of the Carpatho-Balkan Countries, pp. 13-24, 1992.

[30] M. Vivoda Prodan, M. Mileusnić, S. Mihalić Arbanas, and Ž. Arbanas, "Influence of weathering processes on the shear strength of siltstones from a flysch rock mass along the northern Adriatic coast of Croatia," Bulletin of Engineering Geology and the Environment, 2016.

[31] ASTM, "Standard test methods for particle-size distribution (Gradation) of soils using sieve analysis," ASTM D6913-04, 2009.

[32] American Society for Testing and Materials (ASTM), "Standard test method for density of hydraulic cement," ASTM C18815, American Society for Testing and Materials (ASTM), West Conshohocken, Pa, USA, 2015.

[33] ASTM, "Standard test methods for liquid limit, plastic limit, and plasticity index of soils," ASTM D4318-10e1, 2010.

[34] British Standards, "Methods of test for soils for civil engineering purposes. Classification tests," BS 1377-2:1990, 1990.

[35] E. Eberhardt, K. Thuro, and M. Luginbuehl, "Slope instability mechanisms in dipping interbedded conglomerates and weathered marls-the 1999 Rufi landslide, Switzerland," Engineering Geology, vol. 77, no. 1-2, pp. 35-56, 2005.

[36] P. Miščević, D. Števanić, and N. Štambuk-Cvitanović, "Slope instability mechanisms in dipping conglomerates over weathered marls: Bol landslide, Croatia," Environmental Geology, vol. 56, no. 7, pp. 1417-1426, 2009.
[37] ISRM Commision on Testing Methods, "Suggested methods for determining point load strength," in The Complete ISRM Suggested Methods for Rock Characterization, Testing and Monitoring: 1974-2006, R. Ulusay and J. A. Hudson, Eds., ISRM, 1985.

[38] Ž. Arbanas, M. Grošić, and S. Dugonjić, "Behaviour of the reinforced cuts in flysch rock mass," in Proceedings of the 1st International Conference on Transportation Geotechnics, pp. 283-291, September 2008.

[39] G. Vlastelica, The influence of weathering on durability of cuts in soft rock mass [Ph.D. thesis], University of Split, Split, Croatia, 2015 (Croatian).

[40] P. Marinos and E. Hoek, "Estimating the geotechnical properties of heterogeneous rock masses such as flysch," Bulletin of Engineering Geology and the Environment, vol. 60, no. 2, pp. 8592, 2001.

[41] R. P. Miller, Engineering classification and index properties for intact rock [Ph.D. thesis], University of Illinois, 1965. 

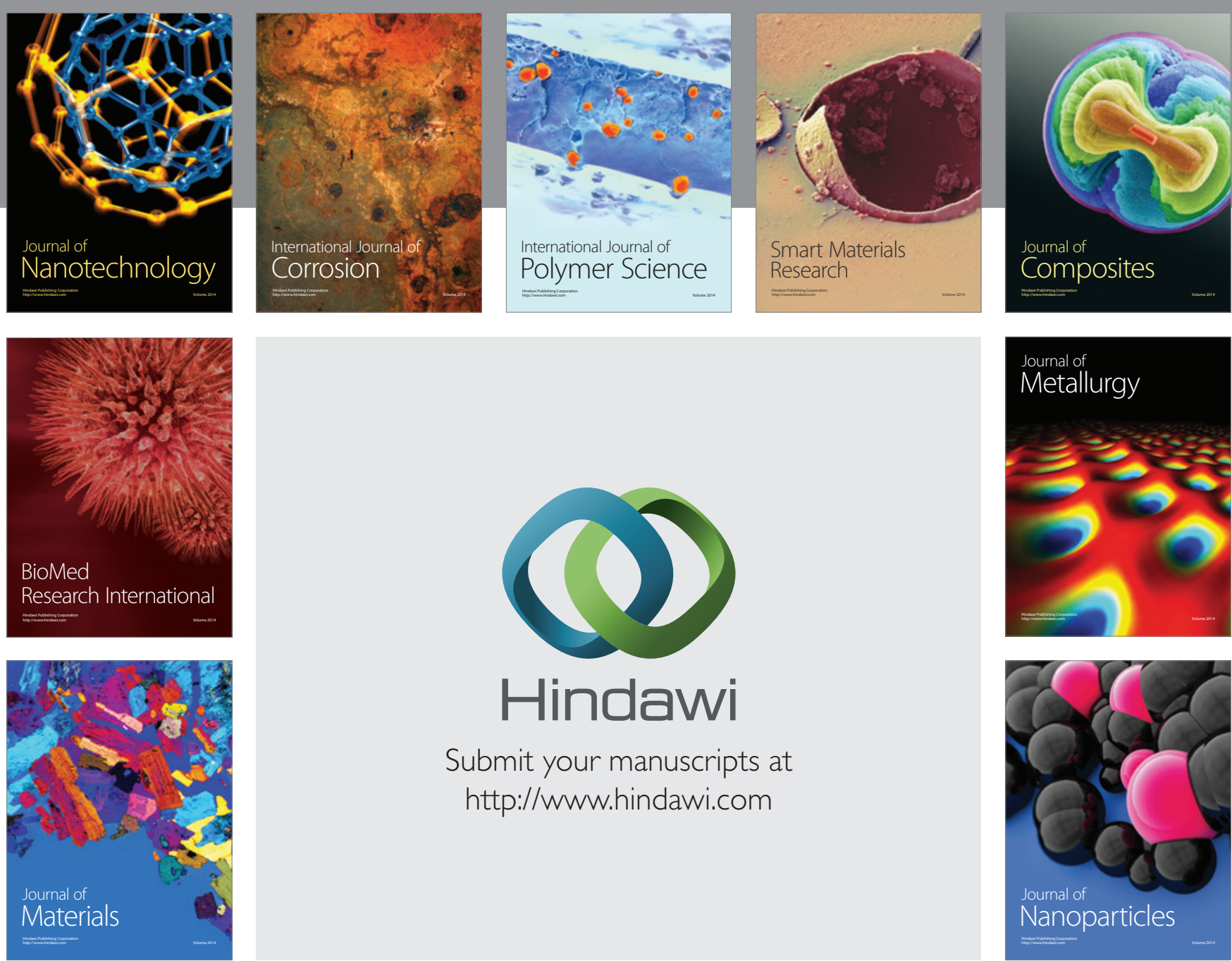

\section{Hindawi}

Submit your manuscripts at

http://www.hindawi.com

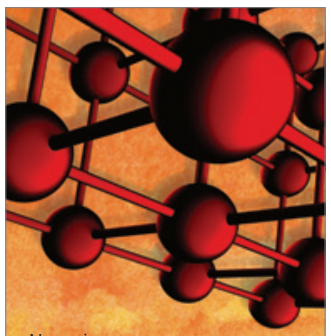

Materials Science and Engineering
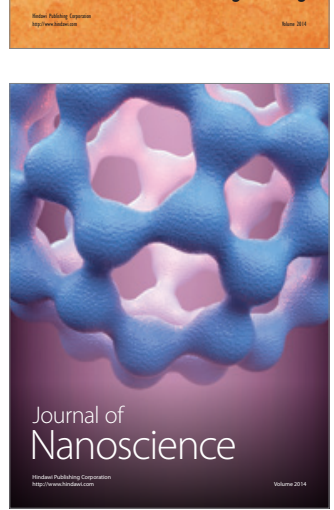
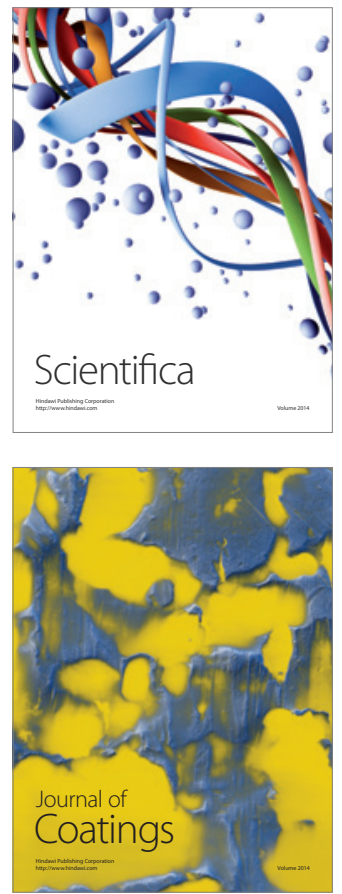
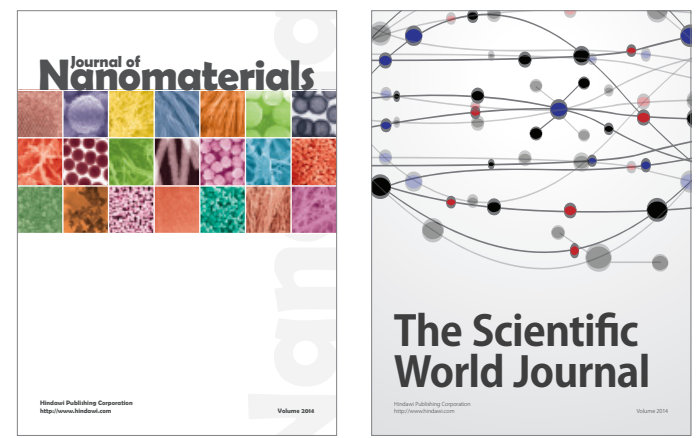

The Scientific World Journal
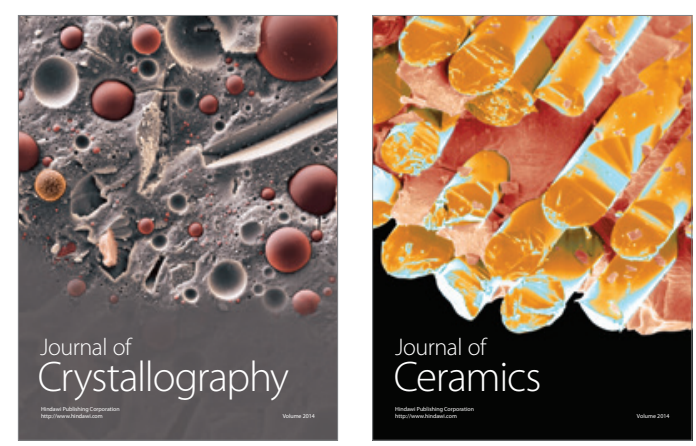
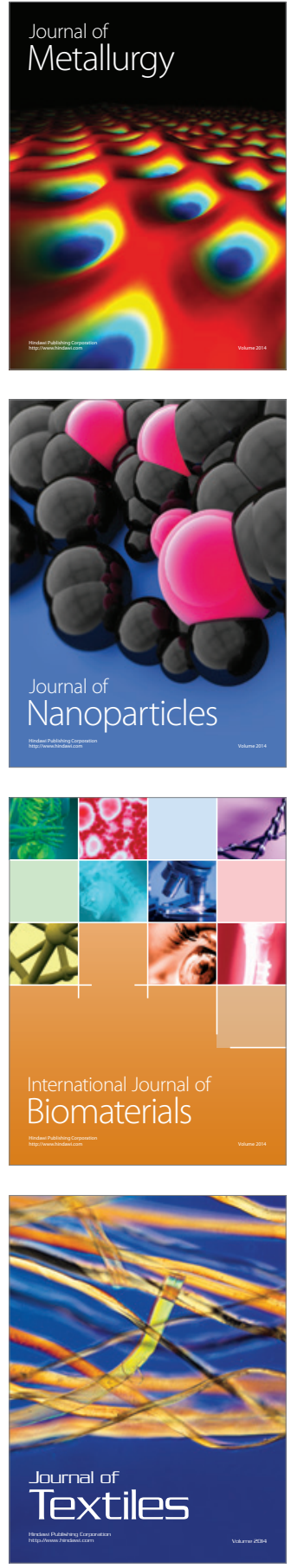